Maurer School of Law: Indiana University

Digital Repository @ Maurer Law

1991

\title{
Law Reform by Courts, Legislatures, and Commissions Following Empirical Research on Jury Instructions
}

\author{
J. Alexander Tanford \\ Indiana University Maurer School of Law, tanford@indiana.edu
}

Follow this and additional works at: https://www.repository.law.indiana.edu/facpub

Part of the Courts Commons

\section{Recommended Citation}

Tanford, J. Alexander, "Law Reform by Courts, Legislatures, and Commissions Following Empirical Research on Jury Instructions" (1991). Articles by Maurer Faculty. 2158.

https://www.repository.law.indiana.edu/facpub/2158

This Article is brought to you for free and open access by the Faculty Scholarship at Digital Repository @ Maurer Law. It has been accepted for inclusion in Articles by Maurer Faculty by an authorized administrator of Digital Repository @ Maurer Law. For more information, please contactrvaughan@indiana.edu. 


\title{
LAW REFORM BY COURTS, LEGISLATURES, AND COMMISSIONS FOLLOWING EMPIRICAL RESEARCH ON JURY INSTRUCTIONS
}

\author{
J. ALEXANDER TANFORD
}

\begin{abstract}
Empirical research demonstrates that jurors have difficulty understanding and following traditional instructions about the law. The social science literature recommends several procedural reforms, including giving important instructions at the start of the trial and providing jurors with written instructions. This article examines changes in the law following the publication of this social science research, comparing courts, legislatures and rule-making commissions. Analysis reveals that although all three institutions are dominated by lawyers, they have acted differently. Commissions have made substantial changes in the law consistent with the recommendations of social scientists, legislatures have made few changes, and courts have changed case law in the opposite direction, suggesting support for a theory of institutional context.
\end{abstract}

\section{INTRODUCTION}

Social scientists often assume that if their empirical research reveals that a law is not operating as lawmakers intended, their discoveries will help spur law reform. However, the anecdotal evidence for empirical research as a motivator of legal change is mixed at best. There have been some apparent successes. In the wake of extensive research on eyewitness unreliability (e.g., Loftus 1979), many jurisdictions have changed the law to allow psychologists to testify about problems with eyewitness identification or to require cautionary instructions (Loftus and Doyle 1987:280, 322). There have also been some spectacular failures. The research demonstrating that death-qualified juries are conviction prone has been presented to many appellate courts but has not produced any change in the law (Thompson 1989:191-94). The U.S. Supreme

The author gratefully acknowledges the support of the Indiana University School of Law, Bryant Garth, and the Center for the Study of Law and Society at Indiana University. The data were presented at the $1990 \mathrm{Law}$ and Society Meetings, and valuable comments were received from Robin Stryker, Phoebe Ellsworth, James Alfini, and others. John Flood provided sound advice on quantitative methodology. I also received helpful comments from Shari Diamond and three anonymous reviewers.

LAW \& SOCIETY REVIEW, Volume 25, Number 1 (1991) 
Court disparaged the research and reasserted its approval of the death-qualification process (Lockhart v. McCree 1986).

A number of theories have been propounded to explain conditions under which social science will be used by legal policymakers. Authors assert that social science is more likely to be used when it is of high quality (Lempert 1988:176), uses dependent measures lawyers can understand (Ruback and Innes 1988:683-84), is accessible (Tremper 1987:272) or has penetrated the culture of the educated elite (Kalven 1968), has been used by other lawmakers (Horowitz and Willging 1984:349-50), has been available for at least five years (Hafemeister and Melton 1987:43-44), and will legitimate decisions reached on pragmatic grounds (Lempert 1988:184; Stryker 1990b). Social science is less likely to be used when it is heavily statistical (Thompson and Schumann 1987), contradicts faith or common sense (Tanford 1990:153-54), fails to support the policy predilections of the lawmakers (Lempert 1988:184-85; Stryker 1990b), would lead to major political disruption (Thompson 1989:202 -4; cf. Stryker 1989, 1990a), demonstrates that something is ineffective without providing a better alternative (Lempert 1988:182), or reflects values incompatible with the jurisprudential principles of the particular area of law (Horowitz and Willging 1984:345-46; Tanford 1990:156-66).

Some law and society literature suggests that the degree to which social science research will affect legal policy depends in part on the identity of the decisionmaker. Different legal actors may be more or less receptive to social science (Lempert 1988). Scattered studies indicate that empirical research has little or no impact on appellate courts (Tanford 1989, 1990; cf. Davis 1987), but may be more likely to influence legislatures and rule-making agencies (Lempert 1988; Stryker 1989, 1990a). This institutional-context theory has been difficult to investigate directly because of the fragmentation of policymaking responsibility within the legal system. In most areas of law, policy will be formulated primarily by either the courts, or the legislature, or a commission, but not by all three.

The law of jury instructions presents a rare opportunity to compare the reactions of courts, legislatures, and commissions to a single body of social science research. All three institutions share responsibility for formulating legal policies about jury instructions, and a substantial body of empirical research on the subject exists. That research demonstrates that jurors have difficulty understanding traditional jury instructions and suggests two procedural reforms: giving important instructions at the beginning as well as the end of the trial, and providing jurors with written copies of their instructions. ${ }^{1}$ These findings have been widely disseminated to the legal community.

1 The literature also recommends that instructions be rewritten in simpler English, avoiding legal jargon and archaic language (e.g., Elwork, Sales, 
Qualitative analysis of legal texts, however, reveals that courts, legislatures, and commissions have acted in quite different ways since the empirical data have become available. Courts have not only ignored the new data but actually have moved the law in the direction opposite to the suggestions of social scientists. Legislatures generally have done nothing or moved slightly toward the suggested reforms. Commissions have made the most substantial changes, engaging in extensive reform of jury instruction procedures along lines suggested by the research.

\section{JURY INSTRUCTION PROCEDURES}

The traditional courtroom procedure for informing juries about the law is for the judge to read aloud a set of instructions at the end of the trial (Tanford 1986:694-95). Giving substantive instructions at the beginning of the trial has been discouraged in most jurisdictions (e.g., Missouri Supreme Court Committee on Jury Instructions 1981:xxxviii). Supplying jurors with written copies of the instructions has been controversial. Some states have explicitly prohibited written instructions (e.g., Alabama Rules of Civil Procedure 51), some have explicitly required them (e.g., Texas Code of Criminal Procedure $\S 36.18$ ), and some have left the matter to the discretion of the trial judge (e.g., California Penal Code $\S 1093$; Schwarzer 1981:756-57).

Between 1973 and 1982, a substantial body of empirical research was published demonstrating that jurors have great difficulty understanding instructions as they are traditionally given (e.g., Charrow and Charrow 1979; Elwork, Sales, and Alfini 1977; Strawn and Buchanan 1976). Among other findings, the literature reported that subject-jurors often understood the law better if they were given preliminary as well as final instructions, and/or if they were given written copies of the instructions (Elwork, Sales, and Alfini 1977:177; 1982:18-20, 155; Cruse and Browne 1987:130-32; Forston 1975:612-16, 619-20; Severance and Loftus 1982:155 n.4). Several of these authors concluded that comprehension of the law could be improved if the laws restricting the use of preliminary and written instructions were changed.

Much of this literature was made readily available to legal policymakers. It was disseminated in law reviews (Charrow and Charrow 1979; Forston 1975), judges' journals (Elwork, Alfini, and Sales 1982; Forston 1973; Strawn and Buchanan 1976; Strawn et al. 1977; Taylor et al. 1980), and books marketed to the legal community (Elwork, Sales, and Alfini 1982). The research supported the views of a minority of judges (Avakian 1979:40; Weltner 1979: 20-21) and legal scholars who had urged these reforms on an intuitive basis (Hunter 1935:8-9; Prettyman 1960:1066). In addition,

and Alfini 1982). No single reform or combination of reforms is likely to solve the entire problem. 
some legal precedent already existed for requiring written instructions (e.g., McElhaney v. State 1967; Texas Code of Criminal Procedure \$ 36.18), or preliminary instructions (Indiana Trial Rule 51). The empirical research thus was both easily accessible to the legal community and suggested reforms compatible with the existing trial system. These characteristics should have increased the likelihood that social science research would have an impact on changing the law (see Hafemeister and Melton 1987:49-50; Ruback and Innes 1988:684-87).

\section{CHANGES IN JURY INSTRUCTION PROCEDURE}

Most of the relevant social science publications appeared between 1976 and 1982. I therefore looked for statements about the law from before and after those dates in all fifty-two United States jurisdictions. ${ }^{2}$ Because civil and criminal trials may be governed by separate laws, preliminary and written instructions may be addressed separately, and the law may be stated in court opinions, legislative statutes, and/or commission rules, a total of 624 possible sources of jury instruction law exist. ${ }^{3}$ Using traditional legal research methods, I found 139 before-and-after pairs of legal texts: 22 pairs of court decisions from 17 different jurisdictions, 53 pairs of statutes from 25 jurisdictions, and 64 pairs of commission rules from 29 jurisdictions (see Appendix). This study reports the findings from all these pairs.

All legal texts require interpretation. Using conventional legal analytical methods, I read each source and characterized its rule of law on the use of preliminary and written instructions as one of five: prohibited, discouraged, optional, encouraged, or required.

I characterized a procedure as prohibited if the legal text contains clear prohibitive language or imposes a punitive sanction for using the procedure. Alabama Rule of Civil Procedure 51 is an example of a direct prohibition: "Neither the pleadings nor the 'given' written instructions shall go into the jury room." The sanction model is illustrated by People $v$. Vincenty (1986:588): "The trial judge [gave] preliminary instructions ... . This procedure violated defendant's right to a fair trial and the error cannot be considered harmless."

I characterized a procedure as discouraged if a legal text states disapproval of the procedure but stops short of outright prohibition, places restrictions on its use, or explicitly requires the use of a different procedure. Taylor $v$. Monroe County (1981:701) contains an example of disapproval language: "[T] he trial court [gave] a copy of the instructions to the jury for use while deliberating.

2 The fifty states, the District of Columbia, and the federal courts.

3 I arrived at the total of 624 possible sources by multiplying 52 jurisdictions $\times 2$ (civil or criminal) $\times 2$ (preliminary or written instructions) $\times 3$ (court öpinions, legislative acts, or commission rules). 
Although this practice is not recommended, ... any error which resulted was harmless." Arkansas Code § 16-64-114 illustrates the restriction type: "It shall be the duty of the trial judge to deliver to the jury ... a typewritten copy of the instructions [only] when counsel for all parties so request." Federal Rule of Criminal Procedure $\mathbf{3 0}$ is an example of a text that implicitly discourages preliminary instructions by explicitly requiring a different procedure: "[T]he court shall instruct the jury after the arguments are completed."4

I considered a procedure optional if the legal text either explicitly takes no position on the use of the procedure, or leaves the matter to the trial judge's discretion. State $v$. Parrish (1985:615) is an example of a no-position law: "[P]retrial instructions to the jury are neither condemned nor approved." Minnesota Rule of Criminal Procedure 26.03(18) is an example of the discretion version: "[I]n the discretion of the trial court, a copy [of the instructions] may be taken to the jury room when the jury retires for deliberation."

I characterized a procedure as encouraged if the legal text recommends the procedure but leaves the final decision to the trial judge's discretion, or establishes procedures that will have the natural effect of increasing its use. Copeland $v$. United States (1945:770) illustrates the recommendation approach: "We think it is frequently desirable that instructions [be] handed over to the jury .... We see no good reason why the members of a jury should always be required to ... rely upon their [memories]. The question should be determined by the judge in his discretion." California Code of Civil Procedure $\S 612.5$ is an example of a law that does not explicitly recommend a procedure, but creates a situation where use of the procedure will probably increase: "Upon the jury retiring for deliberation, the court shall advise the jury of the availability of a written copy of the jury instructions. [I]f the jury requests . . . a copy of the written instructions, the court shall supply the jury with a copy."

Finally, I considered a procedure required if the legal text contains either a simple mandate without room for judicial discretion, or imposes a sanction for not using the procedure. Michigan Court Rule 2.516 illustrates the nondiscretionary mandate: "[B]efore evidence is taken, the court shall give . . . preliminary instructions . . . to enable the jury to understand the proceeding and the evidence." McElhaney $v$. State (1967:645) illustrates the sanction model: "The failure to have the jury take the written charge with them for deliberation constitute[s] reversible error."

To be selected for analysis, pairs of statements about proper

4 It is a general principle of statutory construction that expressio unius est exclusio alterius: the specific mention of one thing implies the exclusion of other alternatives (McCaffrey 1953:50-51). 
jury instruction procedures had to satisfy the following criteria: (1) both came from the same institution-court, legislature, or commission; $;^{5}$ (2) both concerned the same kind of trial-either civil or criminal; (3) both concerned the same procedure-either preliminary or written instructions; (4) both contained a statement of law about that procedure which could be characterized as prohibited, discouraged, optional, encouraged, or required; and (5) one predated 1976 and the other came from 1982 or later.

\section{Appellate Courts}

In seventeen jurisdictions, I was able to find one or more pairs of appellate cases that satisfied the basic selection criteria and that involved no intervening preemptive action by the legislature or any rule-making commission. These opinions are summarized in Table 1. Analysis shows that 63.6 percent $(14 / 22)$ of courts that had an opportunity to change an existing procedural law did not do so, regardless of the substance of that law. Among the eight courts which did change their laws of jury instruction procedure, 100 percent $(8 / 8)$ changed in the negative direction, restricting rather than expanding the use of the more effective jury instruction procedures recommended in the interdisciplinary literature. Negative change occurred even in one case in which the appeals court made indirect reference to the psycholinguistic research (State $v$. McCloud 1984), and regardless of whether the trial judge had given written instructions (Dunn v. Syring 1983) or refused to give written instructions (Sanders v. State 1982).

\section{Legislatures}

In twenty-five jurisdictions, I was able to find one or more pairs of statutes that satisfied the basic selection criteria. These statutes are summarized in Table 2. Analysis shows that 88.7 percent $(47 / 53)$ of legislatures which had an opportunity to change an existing procedural law did not do so, regardless of the substance of the existing statute. However, when legislatures did amend jury instruction statutes, 100 percent changed in the direction that the literature suggests will result in more effective procedures. However, in telephone interviews, none of the legislators who spon-

5 Allocating responsibility for a change in law to a court, legislature or commission is not always easy. For example, in Arkansas the legislature passed 1971 Act No. 470, which authorized the supreme court to establish a commission on rules of procedure. The court delegated this task to the attorney general, who set up a semi-independent commission on which a deputy attorney general held much of the power. This commission recommends rule changes to the supreme court which forwards them to the legislature, where they become law by legislative inaction (see Arkansas Code Court Rules 1990:2). In all such cases of formal ambiguity, I have allocated responsibility to whichever institution has the most significant active role in initiating change, deciding what legal policy should be, and drafting proposed legal rules. 
Table 1. Judicial Opinions on Proper Jury Instruction Procedures

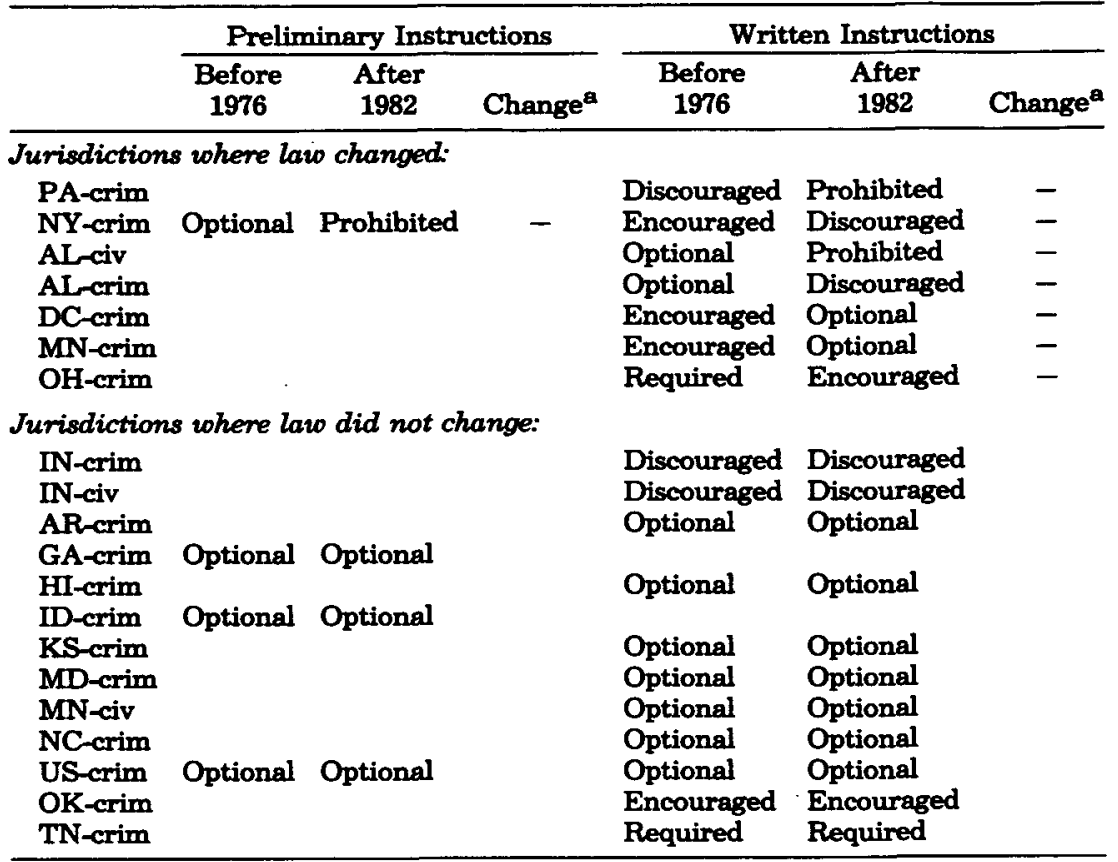

${ }^{a} A$ plus sign (+) indicates change consistent with the social science literature; a minus sign (-) indicates change in the opposite direction.

Thirty-five other jurisdictions did not have relevant cases from before 1976 and after 1982 or had an intervening change in legislation or rule of procedure.

sored law reform legislation reported being aware of the psycholinguistic research on jury instructions. ${ }^{6}$

\section{Rule-Making Commission}

Finally, I analyzed rules concerning preliminary and written jury instructions promulgated by permanent rule-making commissions on civil procedure, criminal procedure, or the courts. Such commissions are established either by state supreme courts or legislatures, have broad rule-making powers, and are relatively independent. I identified rules in twenty-nine jurisdictions that satisfied the basic selection criteria. These rules are summarized in Table 3. Analysis reveals that 78.1 percent (50/64) of commissions which had an opportunity to change an existing procedural law did not do so, regardless of the substance of that rule. Among the fourteen commissions which did change their rules of jury instruction procedure, 100 percent (14/14) changed them in the direction rec-

6 Explanations vary. The Louisiana bill was recommended by the Louisiana State Law Institute and "seemed like a good idea" (interview with Edward C. Gaudin, state representative, Baton Rouge, Louisiana, 15 March 1991). The Georgia bill was introduced by a lawyer-legislator who thought it would be a good idea based on his own experience as a trial lawyer (interview with Roy $\mathrm{E}$. Barnes, state senator, Marietta, Georgia, 14 March 1991). 
Table 2. Legislative Acts on Proper Jury Instruction Procedures

\begin{tabular}{|c|c|c|c|c|c|c|}
\hline & \multicolumn{3}{|c|}{ Preliminary Instructions } & \multicolumn{3}{|c|}{ Written Instructions } \\
\hline & $\begin{array}{c}\text { Before } \\
1976\end{array}$ & $\begin{array}{c}\text { After } \\
1982\end{array}$ & Change $^{a}$ & $\begin{array}{l}\text { Before } \\
1976\end{array}$ & $\begin{array}{l}\text { After } \\
1982\end{array}$ & Change $^{a}$ \\
\hline \multicolumn{7}{|c|}{ Jurisdictions where law did not change: } \\
\hline $\begin{array}{l}\text { MT-civ } \\
\text { FL-crim } \\
\text { VA-civ } \\
\text { AR-both } \\
\text { GA-crim } \\
\text { IL-civ } \\
\text { LA-crim } \\
\text { NE-civ } \\
\text { NV-civ } \\
\text { NY-crim } \\
\text { NY-civ } \\
\text { NC-crim } \\
\text { OK-civ } \\
\text { WV-civ } \\
\text { WY-civ } \\
\text { ME-civ } \\
\text { MT-crim } \\
\text { KS-civ } \\
\text { KS-both } \\
\text { WI-civ } \\
\text { OK-crim } \\
\text { ID-crim } \\
\text { IA-crim } \\
\text { MO-crim } \\
\text { OH-crim } \\
\text { SD-civ } \\
\text { TX-crim } \\
\text { WY-crim } \\
\text { MS-crim } \\
\text { MS-civ } \\
\text { MO-civ } \\
\text { SD-crim }\end{array}$ & $\begin{array}{l}\text { Prohibited } \\
\text { Discouraged } \\
\text { Discouraged } \\
\text { Discouraged } \\
\text { Discouraged } \\
\text { Discouraged } \\
\text { Discouraged } \\
\text { Discouraged } \\
\text { Discouraged } \\
\text { Discouraged } \\
\text { Discouraged } \\
\text { Discouraged } \\
\text { Optional } \\
\text { Optional } \\
\text { Optional } \\
\text { Optional } \\
\text { Discouraged } \\
\text { Discouraged } \\
\text { Discouraged } \\
\text { Discouraged } \\
\text { Discouraged } \\
\text { Discouraged } \\
\text { Discouraged }\end{array}$ & $\begin{array}{l}\text { Discouraged } \\
\text { Discouraged } \\
\text { Discouraged } \\
\text { Discouraged } \\
\text { Discouraged } \\
\text { Discouraged }\end{array}$ & & $\begin{array}{l}\text { Encouraged } \\
\text { Encouraged } \\
\text { Required } \\
\text { Required } \\
\text { Required } \\
\text { Required } \\
\text { Required } \\
\text { Required } \\
\text { Required } \\
\text { Required } \\
\text { Required } \\
\text { Required }\end{array}$ & $\begin{array}{l}\text { Encouraged } \\
\text { Encouraged } \\
\text { Required } \\
\text { Required } \\
\text { Required } \\
\text { Required } \\
\text { Required } \\
\text { Required } \\
\text { Required } \\
\text { Required } \\
\text { Required } \\
\text { Required }\end{array}$ & \\
\hline \multicolumn{7}{|c|}{ Jurisdictions where law changed: } \\
\hline $\begin{array}{l}\text { GA-civ } \\
\text { LA-civ } \\
\text { IN-crim } \\
\text { CA-crim } \\
\text { CA-civ } \\
\text { WI-crim }\end{array}$ & $\begin{array}{l}\text { Discouraged } \\
\text { Optional } \\
\text { Prohibited }\end{array}$ & $\begin{array}{l}\text { Optional } \\
\text { Optional }\end{array}$ & + & $\begin{array}{l}\text { Discouraged } \\
\text { Discouraged } \\
\text { Optional } \\
\text { Optional } \\
\text { Required }\end{array}$ & $\begin{array}{l}\text { Optional } \\
\text { Encouraged } \\
\text { Encouarged } \\
\text { Required }\end{array}$ & $\begin{array}{l}+ \\
+ \\
+ \\
+\end{array}$ \\
\hline
\end{tabular}

a plus sign ( + ) indicates change consistent with the social science literature; a minus sign $(-)$ indicates change in the opposite direction.

brior to 1976, no statute existed; case law discouraged written instructions.

ommended by the empirical research, expanding the use of more effective jury instruction procedures.

Some commissioners apparently considered the psycholinguistic research as one factor supporting law reform. The Pennsylvania Criminal Procedure Rules Committee (1984) cited Elwork, Sales, and Alfini (1982) to support the use of preliminary instructions. The chairman of the Florida Criminal Procedure Rules Committee was personally aware of the social science literature, but reports that it played only an indirect role in the decision 
Table 3. Commission Rules on Proper Jury Instruction Procedures

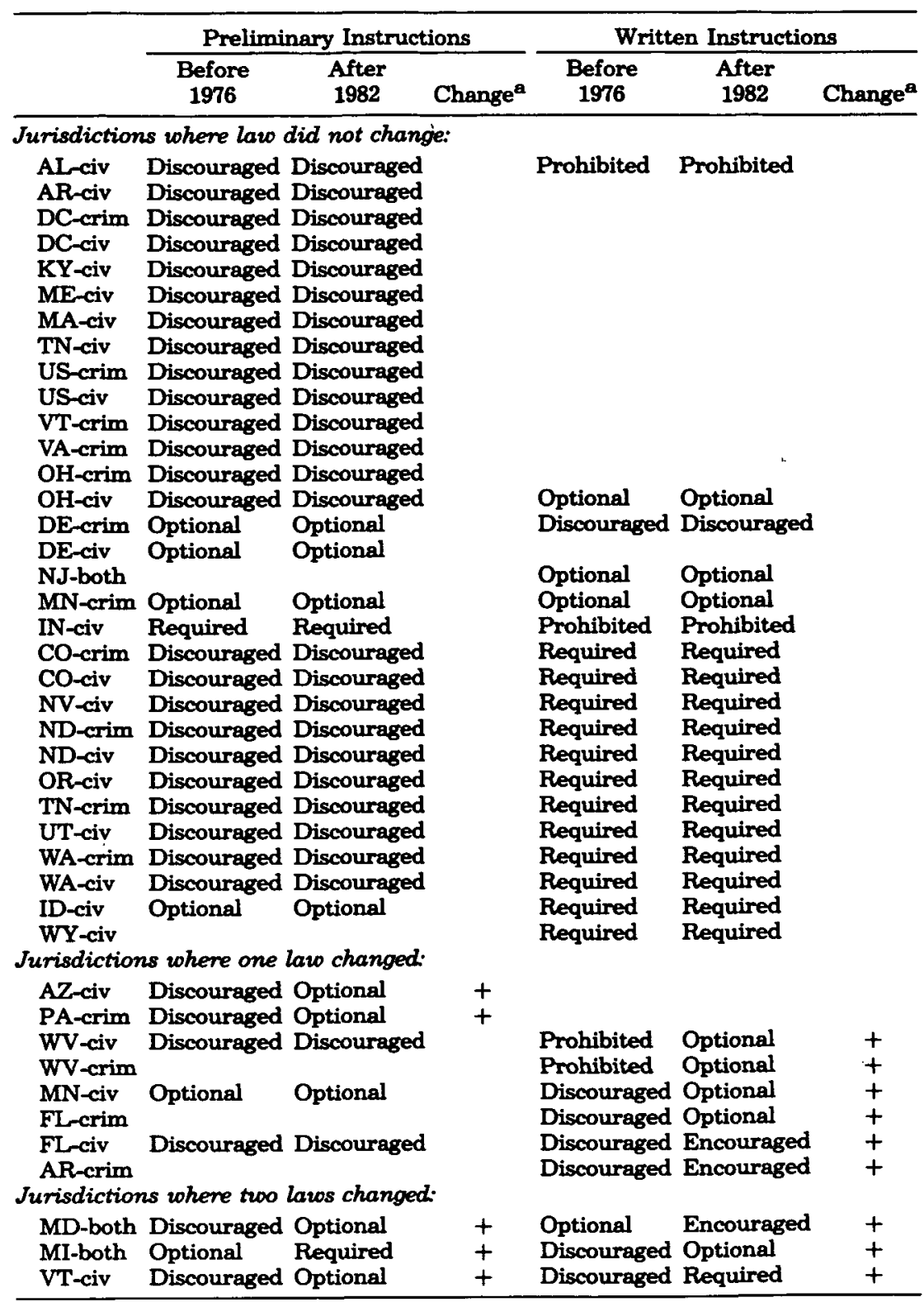

${ }^{a}$ A plus sign ( + ) indicates change consistent with the social science literature; a minus sign $(-)$ indicates change in the opposite direction.

to change the rule concerning written instructions. The main reasons for change were the personal experiences of the judges on the commission. ${ }^{7}$ Vermont's rule was changed in part because of the psychology and in part because other states used written instruc-

7 Interview with Gerald T. Bennett, chairman, Florida Criminal Procedure Rules Committee, Gainesville, Florida, 2 May 1991. 
tions. ${ }^{8}$ Although the official commentary to the new Vermont Rule 51 cites only legal literature to support the change (Nieland 1979:24-30, 32-34), Nieland discusses the psycholinguistic literature (Elwork, Sales, and Alfini 1977; Forston 1975; Strawn and Buchanan 1976). Other commissioners were not aware of the social science literature and recommended changes based on experience and the Manual for Complex Litigation (Federal Judicial Center Board of Editors 1977).9

\section{DISCUSSION}

First, a caveat: The social science research on improving jury instruction procedures is not the only factor that might have contributed to changes in the law since 1976. For example, the change in U.S. political climate between the Carter and Reagan presidencies might be expected to have influenced legal outcomes, especially in criminal cases (see Rowland, Songer, and Carp 1988). Also, ordinary legal evolution is always at work. The law constantly changes, regardless of the existence of relevant empirical research. For example, the Vermont Advisory Committee on the Rules of Civil Procedure decided to require written instructions based partly on the literature and partly on the fact that many other states already encouraged or required them. ${ }^{10}$ Therefore, caution must be exercised in making cause-and-effect generalizations about the impact of social science research on law reform.

In the case of jury instruction procedures, however, I would expect these other factors to operate similarly on courts, legislatures, and commissions. All three institutions are subject to the same kinds of pressures brought about by shifts in political climate. All three bodies are dominated by lawyers. Both appellate courts and rule-making commissions are made up entirely of lawyers. ${ }^{11}$ Lawyers constitute the largest occupational category of state legislators (Bazar 1987:2) and dominate state legislatures (Abel 1988:227; Blair 1967:123-25), especially the judiciary commit-

8 Interview with Kinvin Wroth, reporter, Vermont Advisory Committee on Rules of Civil Procedure, Portland, Maine, 13 March 1991.

9 Interview with David Herr, reporter, Minnesota Advisory Committee on Rules of Civil Procedure, St. Paul, Minnesota, 14 March 1991. See Niemeyer and Richards 1984:303. West Virginia's rule of civil procedure was changed at the suggestion of a trial court judge without knowledge of the empirical research (interview with Ancil Ramey, clerk of Supreme Court, Charleston, West Virginia, 13 March 1991). The Maryland Standing Committee on Rules of Practice and Procedure debated and changed the rules of jury instructions without any mention of the literature (Minutes, October 15/16, 1982:40-43).

10 Interview with Wroth, Vermont (cited in note 8).

11 My conclusion that judges are lawyers is based on experience and common sense. My conclusion that commissioners are lawyers is based on the fact that many states include a list of commission members with their published rules of procedure, almosi all of whom are identified by title either as "Hon." or "Esq." (e.g., Pennsylvania Rules of Court 1990:xxi-xxii). 
tees through which bills concerning court procedure would probably pass. ${ }^{12}$

Evidence suggests that some legal policymakers know specifically about the social science research on jury instruction procedures. The Pennsylvania Criminal Procedural Rules Commission (1984) cited Elwork, Sales, and Alfini (1982). Florida's Committee on Standard Jury Instructions in Criminal Cases included David Strawn, who participated in some of the jury-instruction research (e.g., Strawn et al. 1977; Strawn and Buchanan 1976). The Alaska Supreme Court commissioned law professors Harvey Perlman and Stephen Saltzburg to revise the state's jury instructions, and they explicitly tried to use the suggestions of social scientists (Perlman 1986:520-23). Three published opinions on related issues cite the literature, ${ }^{13}$ and one appellate court decision on the use of written instructions quotes a law review passage referring to "psycholinguistic research" on juror comprehension of instructions (State $v$. McCloud 1984, quoting Schwarzer 1981). Some members of rule commissions indicated they were aware generally of the social science research. ${ }^{14}$

Other evidence suggests that the social science research may have contributed indirectly to changes in the law of jury instruction procedures, even when lawmakers were unaware of it. Although the legal literature had been suggesting changing the law to encourage the use of preliminary instructions for at least forty years (Hunter 1935:8-9; Prettyman 1960:1066), only one state had done so prior to 1976 (Indiana Trial Rule 51). However, seven states changed the law to permit preliminary instructions following the publication of the social science research. Also, some lawmakers were apparently influenced by intermediate legal publications (e.g., Nieland 1979) which made recommendations based in part on the psycholinguistic research. ${ }^{15}$ With the caveat about unwarranted cause-and-effect generalizations in mind, several observations seem warranted:

1. The strongest factor influencing whether the law changes seems to be legal inertia. Laws in place tend to stay in place: $\mathbf{8 8 . 7}$

12 For example, in 1985, 61 legislators chaired judiciary committees in the states listed in Table 2 (Council of State Governments 1985). Of those for whom occupational and educational data were available, 46/50 (92 percent) were lawyers (Who's Who in American Politics 1989-90). Eulau and Sprague (1964:115-17) assert that lawyers dominate state legislatures regardless of their actual numbers. Other legislators come to them for advice on technical aspects of bills. They are respected by other legislators and gain informal power. They also have disproportionate formal power. Lawyers occupy more committee chairs and are disproportionately represented on important committees.

13 Morgan v. LaLumiere (1986) cites Elwork, Alfini, and Sales 1982; United States v. Alston (1976) cites Strawn and Buchanan 1976; and People v. Gonzalez (1980) cites almost all the literature.

14 Interviews with Bennett, Florida (cited in note 7), Herr, Minnesota (cited in note 9), and Wroth, Vermont (cited in note 8).

15 Interview with Herr, Minnesota (cited in note 9). 
percent of statutes, 78.1 percent of rules, and 63.6 percent of appellate case precedents have gone unchanged since the early 1970s. ${ }^{16}$

2. The social science research has had no apparent impact on appellate courts. To the extent that courts have changed the law of jury instructions at all, they have moved in the direction contraindicated by the empirical data. Appellate courts are now requiring less effective instruction procedures, despite research demonstrating how to improve those procedures. Even when courts have been aware of the literature, they have not changed the law in the direction it suggests (State v. McCloud 1984). This is consistent with a growing body of research showing that courts are ignorant of social science, may be hostile to using it as a basis for legal policy, and prefer to base laws on expediency, precedent, and intuition (Haney 1980:159-60; Saks and Baron 1980:3-16, 44, 119, 154; Tanford 1990; cf. Lempert 1988:187-91).

3. The research appears to have had some effect on legislatures and commissions. To the limited extent that these institutions have changed the law, they have moved it in the direction suggested by the empirical research.

4. Although the differences are not great, the amount of change initiated by commissions appears by four measures to be greater than legislative changes. First, commissions reformed the law twice as often as legislatures: 21.9 percent of rules changed, but only 11.3 percent of statutes were amended. ${ }^{17}$ Second, commissions in three states changed both the rules concerning preliminary instructions and written instructions, but no legislature changed both. Third, two commissions went so far as to require the use of the procedural reform, but no legislature went beyond encouraging its use. Fourth, in two states (Florida and West Virginia) that have overlapping rules and statutes, commissions changed the rules but legislatures did not change the statutes. ${ }^{18}$

5. The social science literature appears to have played a greater role in commission decisions than in legislative acts. Among the legislators I interviewed who had sponsored bills to change jury instruction practices, none was aware of the social sci-

16 There is some indication that court-made law changed more frequently than legislative law. Different rates of change may be due to the relative difficulty of ascertaining prior law. It is harder to find prior case law than to look up a statute, so courts have a greater opportunity to change the law by mistake or ignorance.

17 In Louisiana, the bill to amend jury instruction procedures actually originated in and was recommended by a state agency.

18 In Florida (one of the states in which the original research was conducted), two different commissions changed both the civil and criminal rules of procedure to permit or encourage written instructions (Florida Rule of Civil Procedure 1.470; Florida Criminal Procedure Rule 3.390); the legislature did not change the statute requiring that instructions be oral (Florida Statutes $\$ 918.10)$. In West Virginia, a commission changed the civil rule to make written instructions optional (West Virginia Rule of Civil Procedure 51), while the statute went unchanged (West Virginia Code $\S 56-6-20$ ). 
ence literature. For example, the sponsor of the Georgia amendment wrote and introduced the bill because of his own experience as a lawyer. One of his cases had to be tried three times because jurors were confused about their instructions. ${ }^{19}$ The sponsor of the Louisiana bill introduced it because it was recommended by the Louisiana State Law Institute. ${ }^{20}$ In contrast, some commissioners said they were aware of the literature, and that it either had a significant effect on the commission's decisions ${ }^{21}$ or provided background support for their intuition. ${ }^{22}$

\section{CONCLUSIONS}

Courts, legislatures, and commissions all share responsibility for making legal policy concerning proper jury instruction procedures. All have had opportunities to review and change their laws in light of social science research showing that traditional procedures are ineffective. Yet these three institutions have acted differently. Commissions have enacted the most changes consistent with the social science research. Legislatures have changed only a little. Court changes have been entirely in the opposite direction, apparently unaffected by empirical data.

The extreme difference between courts and commissions is particularly surprising. Both are staffed entirely by lawyers. Many members of rule-making commissions are the very judges who sit on appellate courts. The explanation for the different ways they have changed the law may be that lawyers conceive of the roles differently: judges are supposed to value precedent and follow existing law, commissioners to be innovative.

Alternatively, differences in law reform may be due to differences in the way lawmakers gather the information on which they base their policy decisions. In the courts, the parties gather information and present only that part of it that favors their positions. The judge therefore may assume that information (including any social science data) coming from a biased party is unreliable. In the legislature, constituents present information, and legislators act based on public perception of fact rather than fact itself. ${ }^{23}$ Social science at odds with "common knowledge" is likely to be ignored. In commissions, however, the commissioners themselves are responsible for gathering information and gaining personal expertise. They are expected to be active information gatherers, and

19 Interview with Barnes, Georgia (cited in note 6).

20 Interview with Gaudin, Louisiana (cited in note 6).

21 Interview with Wroth, Vermont (cited in note 8).

22 Interviews with Bennett, Florida (cited in note 7), and Herr, Minnesota (cited in note 9 ).

23 For example, if the public tends to believe that executing murderers will deter crime (an empirical assertion), the legislature is likely to base its laws on that perception and to ignore any research showing that deterrence does not work or that executions have a brutalizing effect. 
thus the only legal actors likely to read the literature looking for new information to incorporate into law reform. A full explanation must await future research.

\section{REFERENCES}

ABEL, Richard L. (1988) Lawyers in Society, Vol. 1. Berkeley: University of California Press.

AVAKIAN, Spurgeon (1979) "Let's Learn to Instruct the Jury," 18 Judges Journal 40 (Summer).

BAZAR, Beth (1987) State Legislators' Occupations: A Decade of Change. Denver: National Conference of State Legislators.

BLAIR, George S. (1967) American Legislatures: Structure and Process. New York: Harper \& Row.

CHARROW, Robert P., and Veda D. CHARROW (1979) "Making Legal Language Understandable: A Psycholinguistic Study of Jury Instructions," 79 Columbia Law Review 1306.

COUNCIL OF STATE GOVERNMENTS (1985) State Legislative Leadership, Committees and Staff. Lexington, KY: Council of State Governments.

CRUSE, Donna, and Beverly A. BROWNE (1987) "Reasoning in a Jury Trial: The Influence of Instructions," 114 Journal of General Psychology 129.

DAVIS, Peggy C. (1987) " There is a book out . . $\therefore$ An Analysis of Judicial Absorption of Legislative Facts," 100 Harvand Law Review 1539.

ELWORK, Amiram, James J. ALFINI, and Bruce D. SALES (1982) "Toward Understandable Jury Instructions," 65 Judicature 433.

ELWORK, Amiram, Bruce D. SALES, and James J. ALFINI (1977) "Juridic Decisions: In Ignorance of the Law or in Light of It?" 1 Law and Human Behavior 163.

(1982) Making Jury Instructions Understandable. Charlottesville, VA: Michie Co.

EULAU, Heinz, and John D. SPRAGUE (1964) Lawoyers in Politics. Indianapolis: Bobbs-Merrill.

FEDERAL JUDICIAL CENTER BOARD OF EDITORS (1977) Manual for Complex Litigation. New York: Boardman.

FORSTON, Robert (1973) "Justice, Jurors and Judges' Instructions," 12 Judges Journal 68.

FORSTON, Robert (1975) "Sense and Non-sense: Jury Trial Communication," 1975 Brigham Young Law Review 601.

HAFEMEISTER, Thomas L., and Gary B. MELTON (1987) "The Impact of Social Science Research on the Judiciary," in G. Melton (ed.), Reforming the Law: Impact of Child Development Research. New York: Guilford.

HANEY, Craig (1980) "Psychology and Legal Change: On the Limits of a Factual Jurisprudence," 4 Law and Human Behavior 147.

HOROWITZ, Irwin A., and Thomas E. WILLGING (1984) The Psychology of Law: Integrations and Applications. Boston: Little, Brown.

HUNTER, Robert (1935) "Law in the Jury Room," 2 Ohio State Law Journal 1.

KALVEN, Harry, Jr. (1968) "The Quest for the Middle Range: Empirical Inquiry and Legal Policy," in G. Hazard (ed.), Law in a Changing America. Englewood Cliffs, NJ: Prentice-Hall.

KAPLAN, Martin F., and Gwen D. KEMMERICK (1974) "Juror Judgment as Information Integration: Combining Evidential and Nonevidential Information," 30 Journal of Personality and Social Psychology 493.

KASSIN, Saul M., and Lawrence S. WRIGHTSMAN (1979) "On the Requirements of Proof: The Timing of Judicial Instruction and Mock Juror Verdicts," 37 Journal of Personality and Social Psychology 1877.

KERR, Norbert L., Robert S. ATKIN, Garold STASSER, D. MEEK, R. W. HOLT, and J. DAVIS (1976) "Guilt Beyond a Reasonable Doubt: Effects of Concept Definition and Assigned Decision Rule on the Judgments of Mock Jurors," 34 Journal of Personality and Social Psychology 282. 
LEMPERT, Richard O. (1988) “'Between Cup and Lip': Social Science Influences on Law and Policy," 10 Law \& Policy 167.

LOFTUS, Elizabeth F. (1979) Eyewitness Testimony. Cambridge: Harvard University Press.

LOFTUS, Elizabeth F., and James M. DOYLE (1987) Eyewitness Testimony: Civil and Criminal. New York: Kluwer.

MARYLAND STANDING COMMITTEE ON RULES OF PRACTICE AND PROCEDURE, Minutes, October 15/16 (1982) (photocopy).

McCAFFREY, Francis J. (1953) Statutory Construction. New York: Central Book Co.

MISSOURI SUPREME COURT COMMITTEE ON JURY INSTRUCTIONS (1981) Missouri Approved Jury Instructions 3d ed. St. Paul: West Publishing Co.

NIELAND, Robert G. (1979) Pattern Jury Instructions: A Critical Look at a Modern Movement to Improve the Jury System. Chicago: American Judicature Society.

NIEMEYER, Paul V., and Linda M. RICHARDS (1984) Maryland Rules Commentary. Charlottesville, VA: Michie.

PENNSYLVANIA CRIMINAL PROCEDURAL RULES COMMITTEE (1984) "Proposed Amendments to Rules of Criminal Procedure, Rules 1113 and 1119," 14 Pennsylvania Bulletin 3358.

PERLMAN, Harvey S. (1986) "Pattern Jury Instructions: The Application of Social Science Research," 65 Nebraska Law Review 520.

PRETTYMAN, E. Barrett (1960) "Jury Instructions-First or Last?" 46 American Bar Association Journal 1066.

ROWLAND, C. K., Donald R. SONGER, and Robert A. CARP (1988) "Presidential Effects on Criminal Justice Policy in the Lower Federal Courts: The Reagan Judges," 22 Law \& Saciety Reviewo 191.

RUBACK, R. Barry, and Christopher A. INNES (1988) "The Relevance and Irrelevance of Psychological Research: The Example of Prison Crowding," 43 American Psychologist 683.

SAKS, Michael J., and Charles H. BARON (1980) The Use/Nonuse/Misuse of Applied Social Research in the Courts. Cambridge, MA: Abt.

SCHWARZER, William W. (1981) "Communicating With Juries: Problems and Remedies," 69 California Law Reviewo 731.

SEVERANCE, Laurence J., and Elizabeth F. LOFTUS (1982) "Improving the Ability of Jurors to Comprehend and Apply Criminal Jury Instructions," 17 Law \& Society Review 153.

STRAWN, David U., Raymond W. BUCHANAN, Bert PRYOR, \& K. Phillip TAYLOR (1977) "Reaching a Verdict, Step By Step," 60 Judicature 383.

STRAWN, David U., and Raymond W. BUCHANAN (1976) "Jury Confusion: A Threat to Justice," 59 Judicature 478.

STRYKER, Robin S. (1989) "Limits on Technocratization of Law: The Elimination of the National Labor Relations Board's Division of Economic Research," 54 American Sociological Review 341.

(1990a) "A Tale of Two Agencies: Class, Political-Institutional, and Organizational Factors Affecting State Reliance on Social Science," 18 Politics and Society 101.

- (1990b) "Science, Class, and the Welfare State: A Class-centered Functional Account," 96 American Journal of Sociology 684.

TANFORD, J. Alexander (1986) "An Introduction to Trial Law," 51 Missouri Law Review 623.

L (1989) " 30 Years and Still Waiting: The Negligible Effect of Jury Instruction Research on Judicial Decisions." Presented at 1989 Law and Society meetings.

- (1990) "The Limits of a Scientific Jurisprudence: The Supreme Court and Psychology," 66 Indiana Law Journal 137.

TAYLOR, K. Phillip, Raymond W. BUCHANAN, Bert PRYOR, and David U. STRAWN (1980) "Avoiding the Legal Tower of Babel," 19 Judges Journal 10.

THOMPSON, William C. (1989) "Death Qualification After Wainwright v. Witt and Lockhart v. McCree," 13 Law and Human Behavior 185.

THOMPSON, William C., and Edward L. Schumann (1987) "Interpretation of 
Statistical Evidence in Criminal Trials: The Prosecutor's Fallacy and the Defense Attorney's Fallacy," 11 Law and Human Behavior 167.

TREMPER, Charles R. (1987) "Sanguinity and Disillusionment Where Law Meets Social Science," 11 Law and Human Behavior 267.

WELTNER, Charles L. (1979) "Why the Jury Doesn't Understand the Judge's Instructions," 18 Judges Journal 18 (Spring).

Who's Who in American Politics 12th ed. (1989-90). New York: R. R. Bowker.

\section{CASES CITED}

Copeland v. United States, 152 F.2d 769 (Ct. App. D.C. 1945).

Dunn v. Syring, 425 So.2d 1081 (Ala. 1983).

Lockhart v. McCree, 476 U.S. 162 (1986).

McElhaney v. State, 420 S.W.2d 643 (Tenn. 1967).

Morgan v. LaLumiere, 493 N.E.2d 206 (Mass. App. 1986).

People v. Gonzalez, 430 N.Y.2d 655 (1980).

People v. Vincenty, 501 N.E.2d 587 (N.Y. 1986).

Sanders v. State, 426 So.2d 497 (Ala. Ct. Crim. App. 1982).

State v. McCloud, 349 N.W.2d 590 (Minn. 1984).

State v. Parrish, 327 S.E.2d 613 (N.C. App. 1985).

Taylor v. Monno County, 423 N.E.2d 699 (Ind. App. 1981).

United States v. Alston, 551 F.2d 315 (D.C. Cir. 1976).

\section{RULES CITED}

Alabama Rule of Civil Procedure 51.

Federal Rule of Criminal Procedure 30.

Florida Rule of Civil Procedure 1.470.

Florida Criminal Procedure Rule 3.390.

Indiana Trial Rule 51.

Michigan Court Rule 2.516.

Minnesota Rule of Criminal Procedure 26.03 subd. 18.

Pennsylvania Rule of Criminal Procedure 1119.

Vermont Rule of Civil Procedure 51

West Virginia Rule of Civil Procedure 51.

\section{STATUTES CITED}

Arkansas Code $\S 16-64-114$, Ark. Stat. Ann (1987).

California Code of Civil Procedure, $\S 612.5$, Cal. Civil Code (West 1982). California Penal Code, $\$ 1093$ (West 1982).

Florida Statutes $\S$ 918.10, Fla. Stat. Ann. (West 1986).

Texas Code of Criminal Procedure, $\S 36.18$, Tex. Crim. Pro. Code Ann. (West 1978).

West Virginia Code $§ 56-6-20$ (1991). 


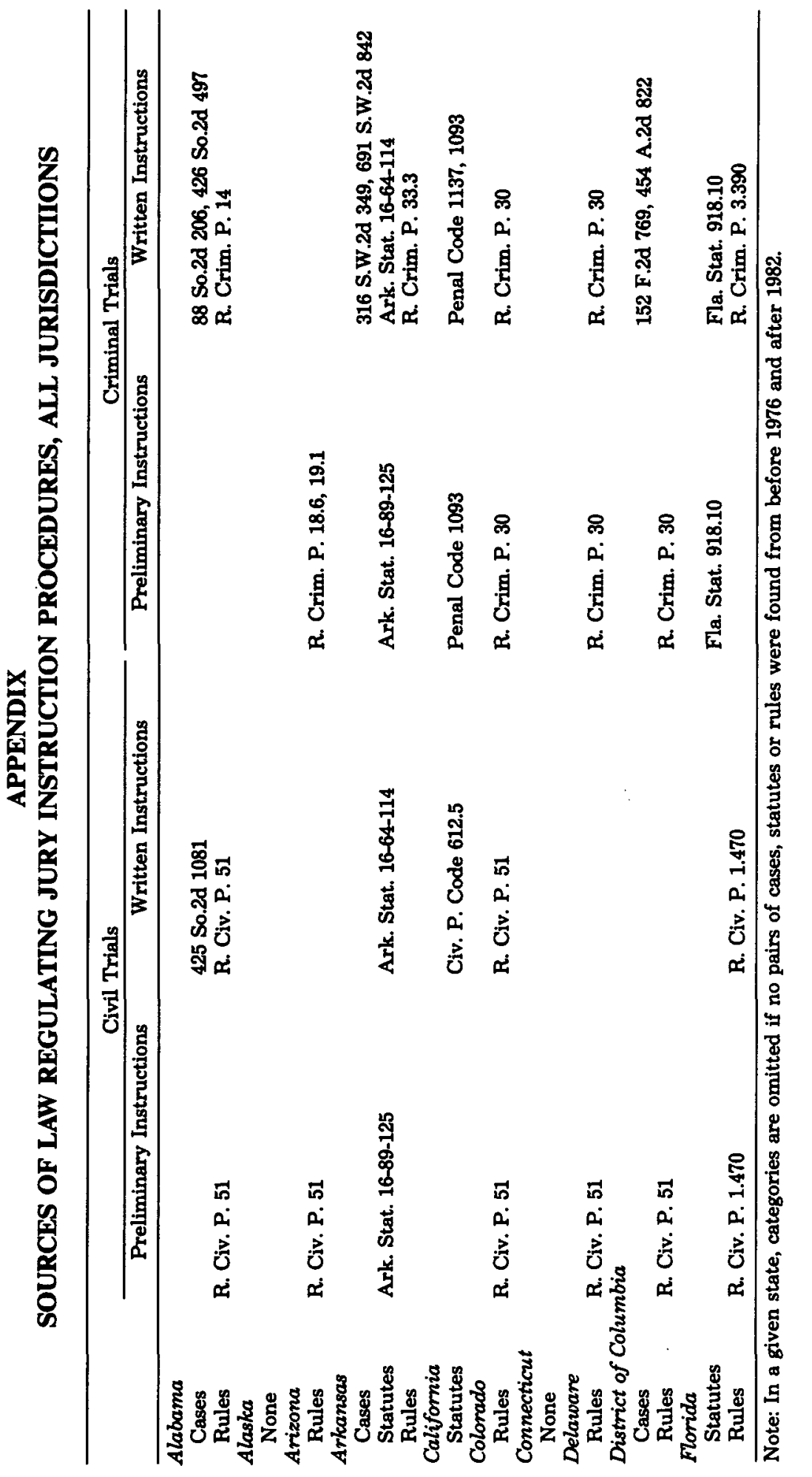




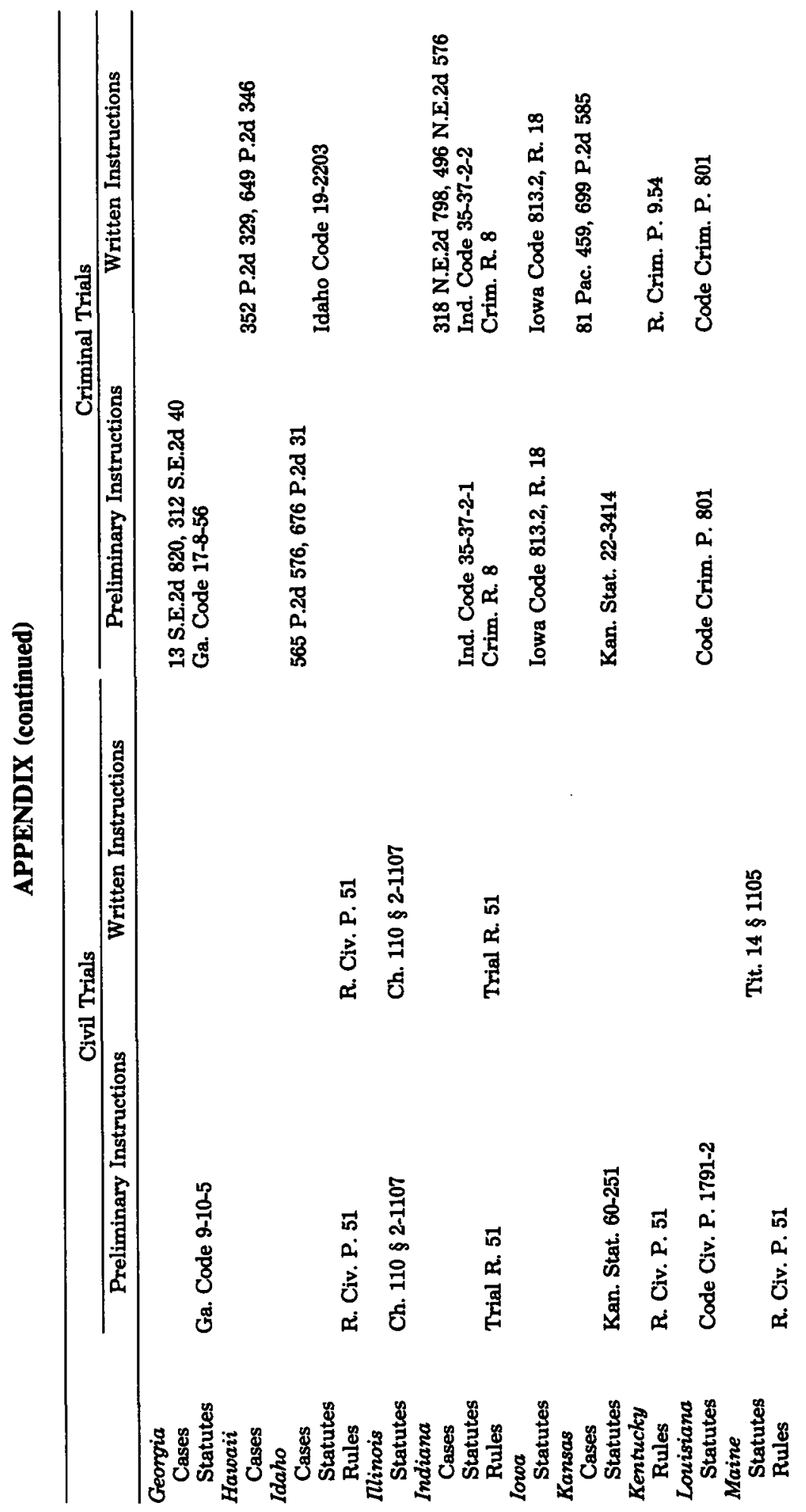




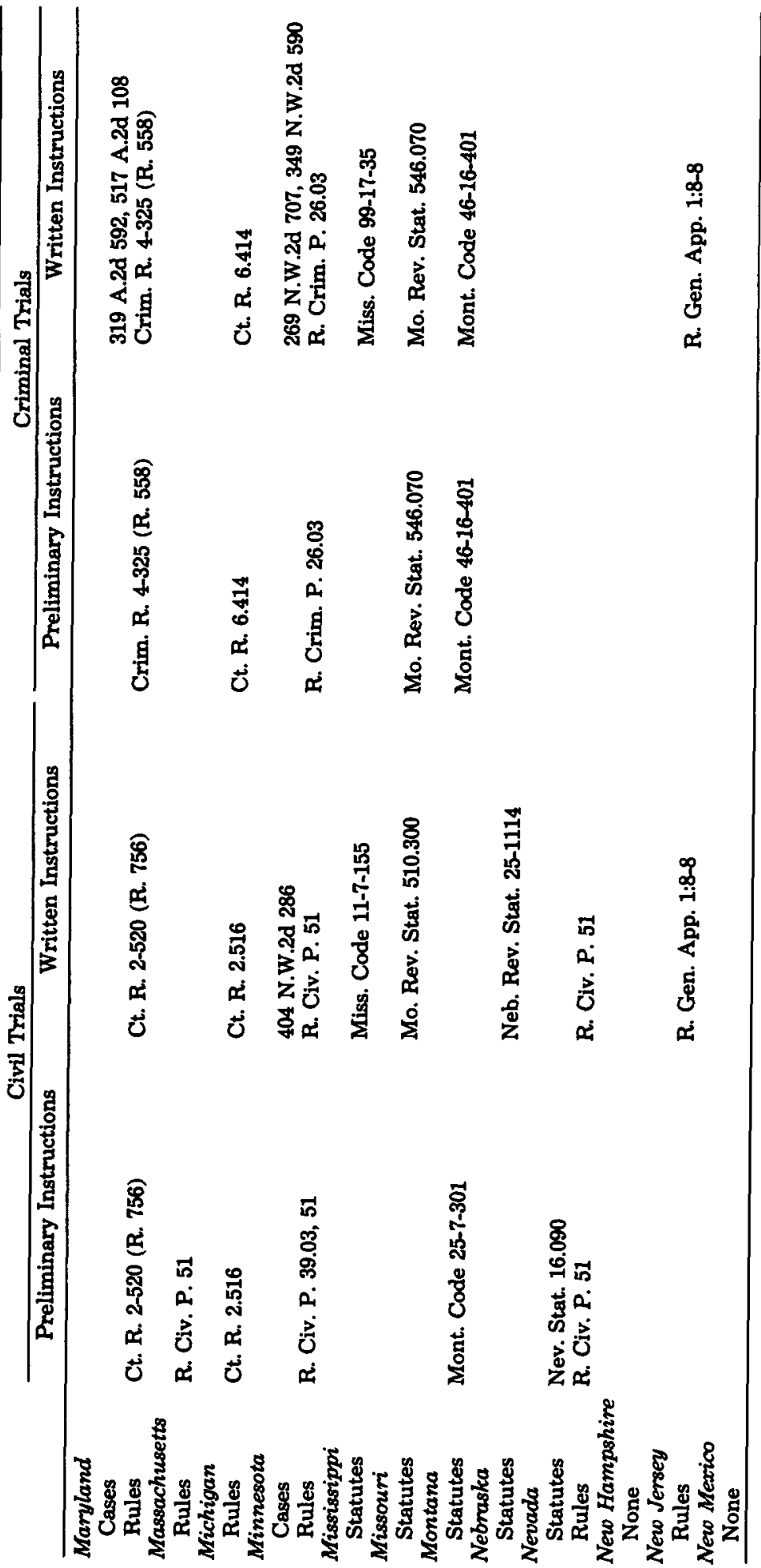




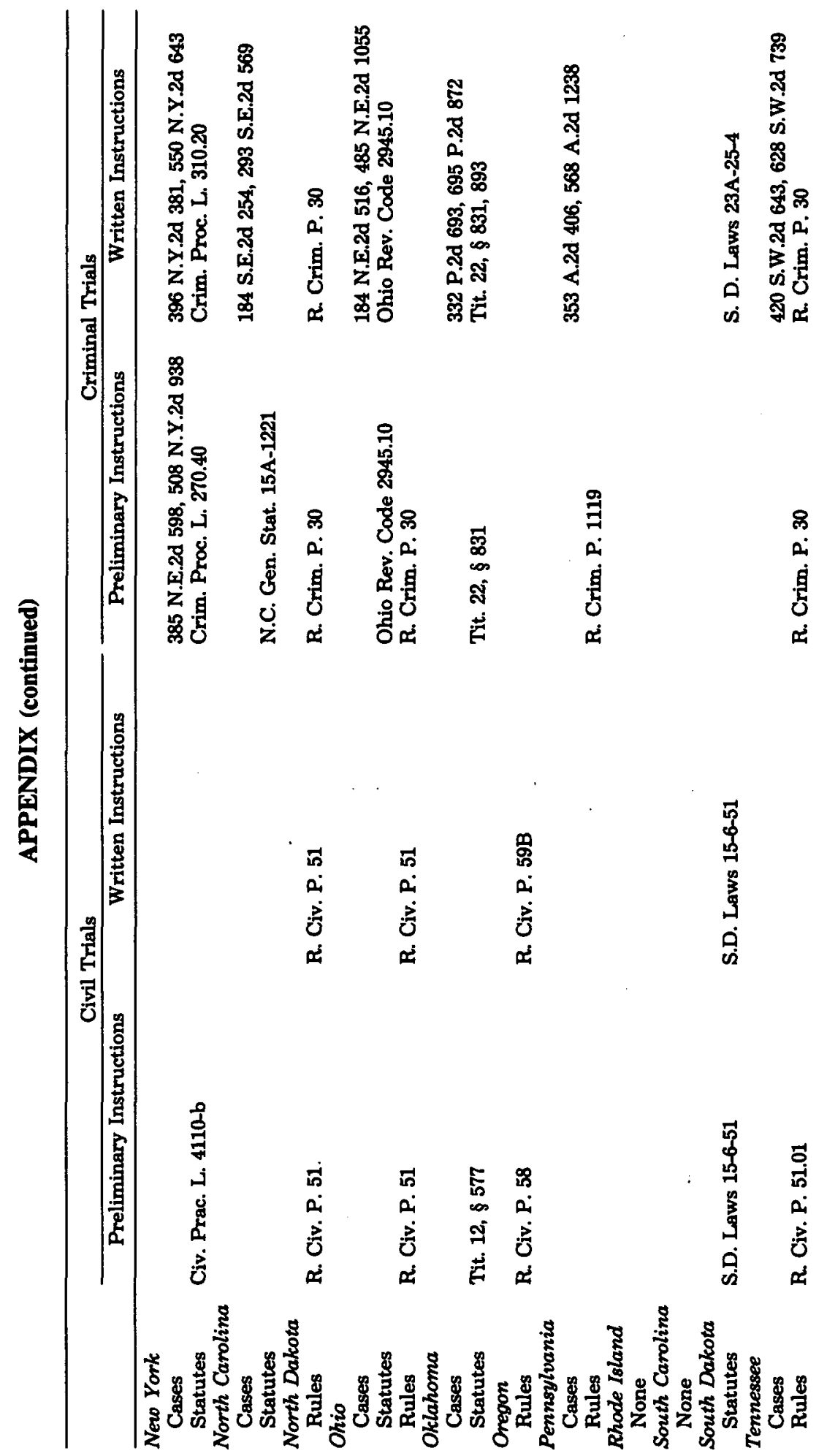




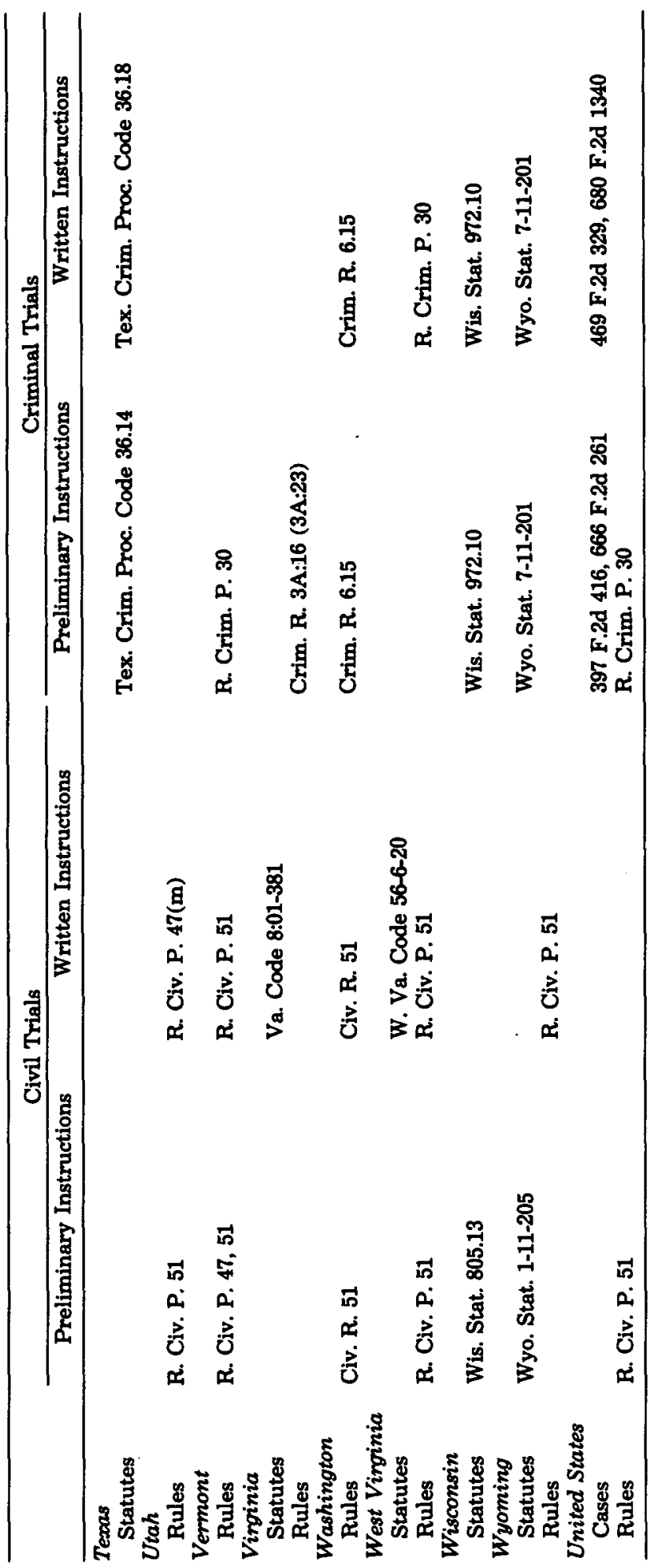


